\title{
紅茶の起源
}

(侏)伊藤園中央研究所*

竹尾忠一

(平成12年 3 月 29 日受理)

\section{The Origin of Black Tea}

\author{
Tadakazu TAKEO \\ ITO-EN CO., Central Research Institute \\ Sagara-cho, Haibara-gun, Shizuoka-ken, Japan
}

\section{1 緒言}

今回中国, イギリスの資料をもとに, Bohea の由来と紅茶の起源についての考察を試み た。

Bohea (ボヒー)という言葉が茶業界に登場 したのは，18世紀始めと考えられる。1702年 イギリス東インド会社の輸入記録に, 上等中 国茶 300 樽とBohea 80 樽とあり1)これが Boheaという銘柄の茶がロンドン茶市場に登 場した始まりである。

\section{Boheaの由来}

1600年代前半, 中国茶はジャワ経由で欧州 に輸出されていた。この時代の茶は主に寧波 辺りから中国籍のジャンクにより，ルソン経 由でジャワに輸出されていた緑茶であった。 1644年イギリスとオランダとの関係が険悪と なり，英国船のジャワ奇港ができなくなった ことで, 英国の貿易商はアモイに集まり中国 交易の基地とした。これが中国特産物が中国 加直接英国に送られるようになった始まり
とされている。そのおりアモイでは茶を夕ま たはテイーと発音していたので，この発音を もとにTeaという英語が生まれたという2)。

そして17世紀末加ら18世紀中葉迄英国に送 られた中国茶は，大部分は広東，アモイから 輸出されたBoheaと呼ばれるものであった と, W. H. Ukersが「Tea and Coffee Trade」 に書いている。

またS. H. Twiningは [The House of Twining, 1706-1956」3)で, 18世紀初頭ロンド ンで売られていた中国茶は, Flowery pekoe, Orenge pekoe, Souchong, Bohea と分類され ていて, Boheaの浯源はWu-i (武夷) に由来 すると記述している。

他方, 広東では発醳茶と考えられる茶が 1500年代には飲用されていたことが，ポルト ガル神父，ガスバール・ダ・クルツ（1556） が本国へ奇せた手紙に,「ここでは地位の高い 人の家を訪問すると, 綺麗な盆に乗せた磁器 のカップに温かい水の様な物を入れて出す習 慣がある。その水を茶と呼んでいて，それは 赤色をした薬のような物である。」文と記載し

\section{静岡県榛原郡相良町女神21番地}


ているところから類推される。

以上のことから16世紀に始まる欧州への中 国緑茶の輸出が，17世紀末になり中国茶の貿 易がイギリス東インド会社の独断場となり, 貿易の中心が広東に移るとともに，中国西南 部で飲用されていた茶 Boheaの，ロンドン市 場への輸出が主体となっていった(表 1 )。ま た当時ロンドンではコーヒーハウスは衰微し て喫茶店が生まれ，庶民の間に喫茶の習慣が 高まり, 英国の嗜好飲料事情に大きな変化が 訪れていた。吕として中国から大量の茶を緑 茶だけで調達することが量的に困難となつた ことと，さらに庶民が飲む茶として安価な茶 の需要が爆発的に増大したことから，広東茶 商がボヒー(Bohea) と名付けた安価な茶の輸 出を䎅ったのであろう。1750～1783年の間の 中国茶のロンドン価格を見ると, 表 2 のよう にBoheaの価格は各茶種の中で最低価格で あった。

\section{Boheaの語源}

それではBoheaという言葉の由来について

\section{表 1 中国茶輸入統計5)}

\begin{tabular}{|lrr|}
\hline & $1721-30$ & $1751-60$ \\
\hline Black tea & $1,000 \mathrm{lb}$ & \\
Bohea & 3,360 & 23,635 \\
Congou & 533 & 532 \\
Suchon & - & 421 \\
Pecko & 111 & 105 \\
Green tea & & \\
Singlo & 4,577 & 11,260 \\
Hyson & 40 & 1,380 \\
Other & 260 & - \\
\hline
\end{tabular}

表 2 茶の価格 ${ }^{3)}$

\begin{tabular}{|clc|}
\hline Black tea & Bohea & $5-8 \mathrm{~s} / \mathrm{lb}$ \\
& Congou & $5-16$ \\
& Pekoe souchong & $10-18$ \\
Green tea & Singlo & $10-12$ \\
& Hysone & 18 \\
\hline
\end{tabular}

注：「The House of Twining」より引用
考えてみたい。この言葉は鳥龍茶誕生の地, また中国銘茶伝説の地武夷に由来するとされ ているが，中国人の発音を聞いてイギリス人 がそれにBoheaというスペルを与えたとする と, Wu-zhi, Wu-yi, 或いはWoo-eという武 夷の清音からその言葉が生まれたとは考えに くw。

最近静岡大農学部の何普明助教授汃ら, 彼 の家郷である浙江省南西部武夷山脈山麓に近 い田舎では，武夷のことを昔からブイと発音 していると教えられた。このことから福建て は古くは武夷をブイと発音していて，武夷産 の茶を中国茶商がブイと発音するのをイギリ ス茶商が聞いて，Bohea (ブヒ一) というスペ ルを与えたものと考えられる。また商売上こ の茶に箔を付けるために，中国銘茶で有名な 武夷の名を，商才にたけた広東茶商が借用し たことも考えられる。

19世紀後葉迄，中国は外国人の内陸部旅行 を堅く禁じていたので，中国内陸部の茶産地 の事情については，貿易地の中国茶商からの 伝聞による以外は知る手だてはなく，イギリ 又貿易商がかの有名な武夷岩茶とBohea とが どのような関係にあるのかは，広東茶商の説 明を信じる外にすべが無かったのが当時の事 情である。

Boheaの銘柄は20世紀始め中国紅茶のイギ リス輸出が衰退するとともにロンドン茶市場 から消えてしまい，また現在の中国茶業界で はその間の事情を知る人はいないことから， 約百年間余中英貿易界の寵児であったBohea の語源をこれ以上確かめることは今のところ できない。

\section{Boheaの産地}

清，劉靖撰「片刻余聞集 1732$\rfloor^{7}$ によると，

「およそ岩茶は全て武夷の各岩山に建つ寺 院，道廟の，僧，道士が摘採して，釜炒り製 茶した物（宫製茶）である。遠近の茶商は武 夷九曲の各寺院にてこの茶を買い付ける。そ の外に福建省(郡)武，また江西省広信府等の 各所 (武夷山脈山麓地帯) で生産される茶に 黒色紅湯（外観黒く，水色が紅色）の茶があ 
る。これは武夷九曲上流の星村の茶問屋で取 引されている。その值は安く茶は粗大である。 近里ではこれを江西鳥といい, 山地部族が星 村に持ち込み売っている。」あり、18世紀中 葉武夷山には釡入茶とは別に, 武夷山脈奥地 で山地部族（軮族：畣は中国語で焼畠の意） により造られていた黒色紅湯の茶が, 武夷の 星村で盛んに取引きされていたことが記述さ れている。

またR. Fortuneがその中国内陸部探検記 $\lceil\text { Tea District of China \& India, } 1853\rfloor^{81} \mathrm{~K}$ も, 彼が外国人として始めて武夷山に密入域 し,この地域の茶業を調查し, 茶樹を収集し た際の記録に,「武夷山では多数の寺院, 道廟 で, 僧, 道士, 作男らの手により茶が造られ ている。この地域の寺院の庭には竹製の棚が 並び，その棚には茶葉を薄く広げた竹ざるが 差し込まれている。土間では火炉が並び僧や 作男が忙しく働いていた。ここで造られた茶 は寺院内での飲用の外に, 寺, 廟の庭先で遠 近の茶商と取引されて, 崇安から武夷山脈越 えで江西省の河口を経て中国各地へと移出さ れている。また星村では大量のBlack Tea(紅 茶）が周囲の山地から集荷され, 上海, 広東 に移出されて輸出用となっている。」記述し ている。

このように18世紀の武夷山地区には釜炒茶 と,これとは別に武夷山の後背山地（武夷山 脈山麓の福建西南山地, 江西南部山地, 広東 東部山地等)で, 江西烏と云はれる発酵茶(日 干紅茶？）が山地部族の手により造られてい て, 武夷の奥, 星村を中心に大量取引されて いて, これがBoheaとしてロンドンに輸出さ れていたものと考えられる。

尚,ここで説明すると中国観光の名所武夷 山は，福建省の西部に南北にわたり連なる武 夷山脈から別れた低い山々により構成されて いる丘陵地帯で, 昔から古文, 詩等で有名な 武夷とはこの地域を指している。ここには100 年程前迄は丘々には寺院, 道廟が建ち, 多く の僧侣, 道士が生活していたが，その後この 地は荒廃して寺院, 道廟は総て滅び, 現在は 観光用の亭が丘の上に建つだけで昔日の面影
はない。また有名な武夷岩茶を産した茶園も， 今では武夷山を歩いても見ることは出来な い。また武夷山脈一帯は清に服従しない山地 部族の居住地で, ここで生産される農林産物 は武夷山地区に運ばれて漢人との間で取引さ れていたとのことである。

\section{Boheaの末路}

阿片戦争（1842）を境として19世紀末には， 紅茶産業の中心がインド，アッサム地方に移 り，ロンドンでのBoheaの市場はインド紅茶 に奪われて，イギリス紅茶界からBoheaとい う銘柄が消えた。しかしMoneyの「The Cultivation \& Manufature of Tea 4 版, 1883」9) には，紅茶の下級銘柄としてBohea (武夷) が 記載されていることから，インドではBohea が紅茶の一銘柄として19世紀末迄残っていた ようである。

他方, 1916年に外務省通商局が出版した「福 建事情」(0)には, 「福建で生産され流通してい る茶の主体は紅茶で, 紅茶は工夫, 小種, 烏 龍, 包種, 団茶その他に分類されていて, 鳥 龍は紅茶全体の 2 分の 1 程度の生産量を占め ている。鳥龍は夏の茶葉から主として造られ るために, その品質は工夫, 小種より劣る下 級紅茶である。」と記載されている。こうよう に20世紀初期の中国茶業界では, Boheaとい う銘柄は無く，烏龍茶が紅茶の一銘柄として 分類されていている。

以上のような事情からBoheaと鳥龍茶とは 同根の茶種で，19世紀末にはイギリスと中国 とで別々の呼称で呼ばれていたのではなかろ うか。

\section{6 武 夷茶}

さて本来の武夷茶にもどり中国文献を調べ ると, 徐表然の「武夷山志1619」を引用した 周亮工撰, 「閩小記, 1655」11)には,「武夷, 紫 帽, 龍山では各地で茶を生産している。この 地の寺僧たちは茶葉を上手に干焙出来ない。 そこで茶葉を摘採後先ず蒸した後釜で焙乾す る。そのため茶の色澤は紫赤となる。」とあり， 武夷茶は17世紀にはまず茶芽を蒸してから菳 
で焙乾した緑茶であった。

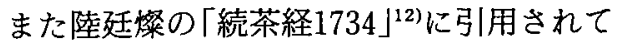
いる「髄見録」には，「建州の茶樹は全て喬木 である。…とれ対して武夷の茶樹は潅木で あり，昔は喬木は見あたらなかった。…茶は 本来光にあたると香味を損なうが，武夷茶は 最初に日光に晒してから造ると良い茶が出来 る」とある。また陸廷燦の「続茶書 1734」 に引用されている「王草堂茶説」 ${ }^{13)} に も$,「武夷 茶。茶葉を摘採後, 竹篭に均一に広げ, 棚に さして風と日光にさらす。これを日晒しとい う。やや葉色の青みが薄くなった時, これを 金で炒る。とある。

このように武夷茶は始めは普通の釜炒茶で あったが，その後茶葉を先ず日晒してから造 る製法に変わっでいる。この日晒し製法につ いては, 16世紀中葉, 明の高滻が日晒し茶(現 在の龍井茶製法に繫ながる）の香味が優れて いることを「遵生八琖 $(1580)\rfloor^{14)}$ に記述してい て，その後，これが中国各地銘茶の製造に応 用されていて, 武夷にもその技術が伝わった ものと考えられる。

\section{7 中国 紅 茶}

武夷に江西鳥という茶が有ったことは前述 の通りであるが,それとは別に武夷の工夫茶, 小種茶の由来についての記述を調べると，前 出の陸廷桑の「続茶経」に「武夷茶は山で造 られた物を厳茶といい，河辺で造られた物を 州茶という。…年のうち品質の最も佳き茶 を工夫茶といい，工夫茶に勝る物に小種茶が ある。これ等は茶樹の名をとり茶の名として いる。とある。つまり18世紀始めの工夫茶, 小種茶は武夷茶の特定銘柄で品種名に由来す る緑茶であったと考えられる。

それでは発酵茶についての漢人の記述はと いうと,それはかなり年月が経った約 100 年後 となる。

宋景藩撰 (1874) [種茶説十条 $]^{15)}$ と, 葉瑞延 撰 (1888)「蒓浦随筆」(6)に紅茶製法が書かれて いるが，それ等を要約すると，「茶生葉を日光 に晒して萎调した葉を積み上げ，足で揉み茶 汁を絞り出したあと，再度日光に晒し，再び
手で良く揉み，その後茶葉を布袋に入れて圧 縮密閉し，茶葉からの発熱を利用して数時間 加温して, 茶葉が銅褐色に変じ茶がしつとり と汗ばんだら，再び日光の下に広げて干し， その後菳で乾燥して茶とする。」書かれてい る。

このように，中国紅茶の製法が漢人の文献 に現れてくるのは19世紀後期であるが，いず れも著者, 年代不詳の原著から引用したもの であり，実際には19世紀始めには既に山地部 族のBohea製造法を漢人は取り入れて，紅茶 を造つていたものと考えられる。

これを裹付けるものとして,「担洋, 白琳, 政和の紅茶は，1850-60年代胡志梅が鳥茶

(Bohea)の製法をまねて造り，始めは星村で 売買していたが後には直接外地に輸出した。」 という記録があり, 湖南の安化県, 巴陵県, 湖北の諈陽県, 安徽の祁門県等の紅茶も, 1850 年前後に福建から製茶技術を導入して生れた ものである。

また中国紅茶製造法がFortune ${ }^{17}$ によりイ ギリスに紹介されたのが1853年であり，その 後アッサムでこの方法に準拠した紅茶製造法 が普及したのは，Moneyの著書 ${ }^{18)}$ から見て 1870年以前であることからも，中国での漢人 による紅茶製造が19世紀初頭には始まってい たのではなかろうか。

\section{8 烏 龍 茶}

もう一つの発酵茶, 烏龍茶の起源を訪ねる と次のような仮説が生まれる。元来18世紀代 には中国には鳥龍茶なる銘柄は無く, 緑茶と 紅茶の 2 種に分類されていた。この内, 緑茶 は漢人が造り漢人が飲用する茶であり，他方 紅茶は山地部族が造り彼等が飲用する茶で あった。それがイギリス貿易が始まるととも にロンドンで名声をはくし，中国茶貿易業界 の主商品として登場した。漢人は最初の内は Boheaをつまるところは赤毛外蕃の飲物とし てしか見ていなかったが, Boheaの世界的需 要が高まるとともに，閩北地方で漢人による Boheaの生産が始まり，19世紀にはこれが中 国紅茶の一銘柄となつた。さらに茶の輸出量 
が延びるとともに，Boheaの生産は武夷より も海岸に近く流通に便な, 閩南の安渓茶産地 へと主産地が移動し，また製造法の改良も進 み現在の鳥龍茶に発展したと考えられる。

安渓の茶についての記述を調べると，その 初出は「安渓県志1552 ل19)で「常菜, 崇善等里 に茶産す」とあり，かなり古くから緑茶の生 産が行はれている。19世紀に入りBoheaの貿 易増大ととともに安渓の茶産地はBoheaの生 産に力をいれ，20世紀始めには閩北茶産地の 衰退とともにそれに代わる茶産地となった。

\section{9 結㝘}

中国の福建, 武夷山脈の山麓に法, 山地部 族により造られていた江西鳥 (発酵茶) が16 世紀頃からあった。17世紀末この茶はイギリ ス人によりロンドンに紹介され，間もなく中 国僻地の一地方茶からBoheaとして世界の茶 に成長した。やがて中国でもこの山地部族の 茶をもとにして，19世紀中葉，中国紅茶が誕 生し鳥龍茶が生まれた。そして19世紀末には， このBoheaから現在の英国式紅茶がインド・ アッサムで創られその産業化が成功した。こ れが中国，インドでの発酵茶史の経緯といえ よう。

\section{0 引用文 献}

1) 春山幸行夫；紅茶の文化史 p55 (1991)， 平凡社.

2) 同上；p54

3) S.H. Twing; The House of Twining 1706-1956 (1956), Published by R. Twining \& CO.LTD. (London)

4) B.S. Dodge (白幡節子訳)；世界を変えた 植物 $\mathrm{p} 135$ ，(1988)，八坂書房.

5 ）角山栄；茶の世界史 p51（1980），中央 公論社.

6 ) 同上, p32-46 (1980).

7 ) 陳祖相, 朱自振編；中国茶葉歷史資料輯, p367（1981），農業出版社（北京）。

8 ) R. Fortune; Tea Disrict of China \& India, p232, 238, 246 (1853), Published by John Murray, (London)
9 ) Lieut-Col. E. Money; The Cultivation \& Manufacture of Tea, 4th Edition, p137 (1883), Publised by W.B. Whittingham \& Co. (London)

10）外務省通商局編纂：福建事情，p193～p 197 (1917)，敬成社.

11）陳祖槼，朱自振編；中国茶葉歴史資料輯 p341

12）同上； $\mathrm{p} 362$

13）同上； p363

14）同上；p301

15）同上； p417

16）同上；p428

17) R. Fortune: Tea District of China \& India, p278-279

18) Lieut-Coli, E. Money: The Cultivation \& Manufacture of Tea, p123-130

19）呉覚農編；中国地方志茶葉歷史資料輯， p348（1990），農業出版社（北京） 